\title{
From Drummond to Boaventura: In Search of Humanities in Scientific Epistemology
}

\author{
Lucimar Almeida Dantas \\ Universidade Lusófona de Humanidades e Tecnologias, Lisbon, Portugal
}

\begin{abstract}
This article presents an analysis of the search for the meaning of life and human happiness linked to science, from an interdisciplinary approach that includes two texts from different areas, that is literature in a specific poem $O$ homem; as viagens (Man; Travels) (Andrade, 1973) and sociology in the book Um Discurso sobre as Ciencias (A Discourse on the Sciences) (Santos, 1997). Parallels are drawn between the two texts, regarding the paradigm of modernity, the quest for human happiness through science, the decline of mechanistic positivist ideals, and the emergence of a new integrative, complex paradigm. Representing areas until recently seen as opposites, both texts offer us insights from different ways of thinking and the use of words that allow us an accurate view of the human ideal of achievement, whether through scientific knowledge, or self-knowledge and with the action of coexistence.
\end{abstract}

Keywords: paradigm of modernity, scientific knowledge, emerging paradigm

\section{Introduction}

Fortunately, I live in an age that allows me to bring science closer to poetry in an academic work and approach texts that make different uses of words, but share similar themes and ideas.

I place myself in the emerging paradigm that views the scientific establishment as the approximating literary or artistic creation, with the intention that the active dimension of the transformation of reality subjects itself to contemplation of the result. Time in which scientific knowledge aims to teach how to live and translate into practical knowledge (Santos, 1997). Time in which, as stated in an interview with Rechikian (1993, p. 71), "... Each one can only depend on the strength of his word".

It is from this perspective that I will try to find common ideas between poetry and science, drawing a parallel between the poem Man; Travels, by Carlos Drummond de Andrade, written in 1973 and the book $A$ Discourse on Sciences, by Boaventura de Sousa Santos, written in 1997, aware that I would find many difficulties to make such an analogy for two reasons: First, as artistic language allows numerous interpretations, and mine being only one among many possibilities; second, knowing that talking about the emerging paradigm is an arduous task, given the "truths" and "values" present in our conceptions, coming from modern science, which, whether I am conscious or not, are still very present in mental structures (Piaget, 1967) with which I interpret the world (Vygotsky, 1999) and therefore will be in my analyses and interpretations.

Lucimar Almeida Dantas, Interdisciplinary Research Centre for Education \& Development (CeiED), Universidade Lusófona de Humanidades e Tecnologias. 


\section{From Modern Science to the Emergence a New Paradigm}

The term "paradigm", originally used by Kuhn (1962) to designate a structure generating a set of values, beliefs and ways of thinking, shared by a society at a particular time, later on got an extension of meaning, with Morin (1992), referring to the term as the principle of organization of theories. In this context, the logic of the discussions within a scientific community is controlled by concepts and relationships imposed by a paradigm. For Morin (1992), a paradigm allows both the existence of dominant theories as well as the appearance of opposing theories, characteristic of a multi paradigmatic reality.

Scientific revolutions do not happen in space or suddenly, but from something pre-existing that is renewed and modified, in a slow and continuous manner. In the field of cognition, such a process is explained by Piaget (1973) with the concepts of accommodation and assimilation, as well as by Piaget and Garcia (1987) for whom the restructuring processes are constituted from something which exists and is characterized by lack of sequence, imbalances, and rebalancing.

Since this is a natural process in the evolution of knowledge built by human beings, from time to time the well-known explanatory models come into question for not responding more to new issues, coming into crisis. From the crisis emerge new models, which are intended to be more comprehensive and more explanatory, a constant process of re-construction and an expansion of knowledge.

It is in this field that we experience, from the late nineteenth century, a change in the way of interpreting reality and of conceiving the world, marked principally by the breakdown of ideas arising from what prevailed in modern science up till then. This change, however, does not have a fixed date. The processes of change are always long and begin within the heart of a dominant explanatory model.

Studies such as those of Darwin are examples of this slow change, as well as the advent of new ways of thinking, that question the existing the paradigm. In addition to contributions in the area of biology, studies by the British naturalist established a new worldview, as a system in a constant process of evolution and change.

In the field of physics, Einstein's Theory of Relativity proved that it was not possible to verify the simultaneity of distant events, only to define it, as arbitrary. According to this postulate, we identified that the measurements of space and time in the universe are relative and depend on the distribution of matter (Moraes, 1996). Also in the area of physics are studies that question the concept of the reality of matter by demonstrating that atoms are not indestructible, possessing space in which moves tiny particles, demonstrated by the experiments carried out by Rutherford, as well as a dual vision of the subatomic world observed by Bohr (1988), who in his Principle of Complementarily demonstrates the duality of form the vision of matter as particles or as waves, depending on how the subatomic units are approached.

Since then, there is evidence of the existence of phenomena as interconnections and which are no longer originating from isolated facts.

All these findings raise serious questions about the paradigm of modernity and the explanations for the phenomena, based solely on mechanistic and positivist character. Having its foundations shaken to the core by the discoveries of areas considered as "real science", the paradigm collapses, and a new, broader, integrative and multidisciplinary proposition appears.

It is in this context that we see a new base of more humanized knowledge arise, in order to rescue from the ashes, from the margins of the modern that which was put in the background for not meeting the scientific character of the time. An integration across the various areas of knowledge is sought after, previously 
considered as separate and opposite, to try to understand the complexity of phenomena, above all human phenomena which cannot be measured or quantified.

This paradigm is called "New Covenant" (Prigogine \& Stengers, 1979), "New Physics and Physics of Taoism" (Capra, 1983, 1984 ), "Paradigm of Self-Organization" (Jantsch, 1980), "Post-Industrial Society" (Bell, 1976), "Communicative Society" (Habermas, 1982), or "Paradigm of Prudent Knowledge for a Decent Life" (Santos, 1997). Regardless of the name and the differences between the various propositions, they all converge on a well-known model, for this reason complex, non-dualistic, based on overcoming distinctions between natural sciences and social sciences, with a tendency to returning to value humanistic studies (Santos, 1997).

It is under such a conception which seems to follow a comparative analysis between two texts from different fields, literature and sociology, which together bring an analysis of the topic in question.

\section{From Drummond...}

\section{Man; Travels}

Man, beast of the earth so

Small

bores of the Earth.

Place of much misery and little

Fun

builds a rocket, a capsule,

a module

touches the Moon

lands carefully on the Moon

Steps on the Moon

plants flag on the moon

tries out the Moon

colonizes the moon

civilizes the Moon

humanizes the Moon

Humanized Moon: same as

the Earth.

Man gets bored with the Moon

let's go to Mars - order your

machines.

They obey man

land on Mars

Step on Mars

tries out

colonizes

civilizes

humanizes

Mars with a device and art.

Humanized Mars, what a square

place.

Let's go somewhere else?

Of course-says the device

sophisticated and sweet. 
Let's go to Venus.

Man puts his foot on Venus

sees the view-Is this it?

Well

Well

Well.

Man blows his mind if he does not go to

Jupiter

proclaims justice with injustice

repeat the dumb thing

repeating the repetitive

disquiet.

Other planets are left to other

colonies.

All of space turns earth-to-earth.

Man arrives at the Sun or goes on a

trip

only to see you?

He doesn't see what he invents

fireproof clothing to live in the sun

Set foot on and

But the sun is boring, fake bull

Spanish tamed

There are other systems remaining out there

Than the sun to colonize

When all ends

It only remains for man

Will he be equipped?

For the very difficult most dangerous

Trip

From himself to himself

Step on the ground

Of his heart

Try out

Colonize

Civilize

Humanize

Man

Discovering in his own

Unexplored inner self

A perennial unsuspected joy

Of coexistence

...to Boaventura

In "man as beast of the earth / small / bores the earth / place of such misery and little / fun", we find ideas similar to Santos' (1997), when he presents the dominant paradigm. Here we see one of the main characteristics of a paradigm of modernity - a break with the models that preceded it and a new vision of the world and life, taking science as a promise to solve all the problems and miseries of Earth.

The Earth symbolizes the old, the archaic, common sense and the humanities that modern science despises and does not consider knowledge, because they are not quantified. So man builds "a rocket, a capsule, and 
sends a module to the Moon". Notice that man "builds", knowledge is the result of an action of a subject on an object; mechanism and power of machines are the promise of science conquering the moon a metaphor here is the unknown, new progress.

Man "lands carefully...", "steps on the Moon”, "plants a flag... ”, “... tries out”, “colonizes... ”, “... civilizes", "humanizes...". All these actions are carried out as the dominant paradigm; soon, landing carefully does not mean respecting differences and recognizing them, but to observe, measure, classify; to step, experiment, and plant a flag means taking the Moon as his, taking nature as simple and regular, able to be observed and measured accurately (Santos, 1997). To colonize, to civilize, and to humanize denote imposing totalitarian truths of modern science and demonstrating the predominance of cognitive-instrumental rationality (Santos, 2005).

In the following two stanzas, we see the need for man for even more knowledge through more mechanism. "Humanized moon is equal to the Earth / Man gets bored with the Moon / Let's go to Mars—ordering their machines". The world is seen as a place of order and stability; it is a machine whose operations can be determined through physical and mathematical laws: "land on Mars / Step on Mars / colonizes / civilizes / humanizes Mars with device and art". The mechanistic determinism — a form of utilitarian and functional knowledge - has the ability to dominate and to transform, but not to profoundly understand reality.

Also note that the idea of the past repeats itself in the future, "man puts his foot on Venus / see the view-is this it? / Well / Well / Well".

The fourth stanza and the beginning of the fifth represent the supremacy of the dominant paradigm and its unbridled quest for more and more technological advances: "Man blows his mind if he does not go to Jupiter"; "Other planets are left for other colonies / All of space turns earth-to-earth"- to reach its peak- "man arrives at the Sun". The sun here is a metaphor for the biggest challenge posed to man, the hardest achievement that now, with the development of the machine, of the rational and the positive that has been achieved.

One can also see the attempt to solve the problems created by the mechanism with more mechanism, looking for an answer that can no longer be found in the paradigm itself: "proclaim justice with injustice / repeat the dumb thing / repeat the repetitive/disquiet".

However the sun, having been conquered, there are no more challenges to face. The Sun is "boring", "fake Spanish bull tamed"; according to Santos (1997, p. 24), "the great advance in knowledge brought about by the paradigm of modernity allows us to see the fragility of the pillars that held it up". Science does not fulfill its promise to solve all the world's problems; on the contrary, it has made many of them worse and is no longer able to solve those that it has created so the paradigm dives into a deep crisis "There are other systems remaining out there / than the sun / to colonize".

Next, Drummond announces what Boaventura calls the emerging paradigm: "when all ends it / only remains for man / (will he be well-equipped ) / the very difficult, the most dangerous / travel / from himself to himself / step on the ground / of his heart / try out / colonize / civilize / humanize / man / discovering on his own / unexplored inner self / perennial unsuspected joy of / coexistence".

The answer was sought in the entire universe through scientific advancement under the paradigm of modernity but was not found, because we are not machines and without us they do not exist. As stated by Santos (1997, p. 30):

After the euphoria of the nineteenth century scientist and consequent aversion to philosophical reflection, well 
symbolized by positivism, we come to the end of the twentieth century possessed by an almost desperate desire to have a complete knowledge of things, that is, knowledge about and within ourselves.

The paradigm which arises is due to a society revolutionized by science, so it cannot just be scientific, it must also be social and have at its core subject, the revaluation of the humanities and knowledge left behind by modern science.

We can see a comprehensive and intimate knowledge appears- "step on the ground / from your heart"-arising from the relationship between two individuals but not between a subject and an object: "discovering ..." "... the perennial unsuspected joy / coexistence" - which unites us to what we study and whose quality is assessed by personal satisfaction which is given to those who he accesses and shares it.

The two analyzed texts, even though they were written at different times by authors of fields that are nothing alike, in distinctly different languages, reveal related messages, dealing with the appreciation of the human condition in all its complexity and beauty. Neither the time nor the place is important, human beings are always human; there is no problem that passes by us and for which a good solution cannot be found, if it is not first searched for within ourselves, always considering our weaknesses and unknown potential.

\section{References}

Andrade, C. D. (1973). O homem; as viagens. In As Impurezas do Branco. São Paulo: Graña Drummond.

Bell, D. (1976). The coming crisis of post-industrial society. New York: Basic Books.

Bohr, N. (1988). Teoría atómica y descripcción de la naturaleza. Madrid: Alianza.

Capra, F. (1984). The Tao of physics. New York: Bantam Books.

Capra, F. (1983). The turning point. New York: Bantam Books.

Habermas, J. (1982). Theorie des Kommunikativen Handelns (2 vols). Frankfutt: Suhrkamp.

Jantsch, E. (1980). The self-organizing universe: Scientific and human implications of the emerging paradigm of evolution. Oxford: Pergamon.

Kuhn, T. S. (1962). The structure of scientific revolutions. Chicago: University of Chicago Press.

Moraes, M. C. B. (1996). O paradigma educacional emergente. Tese (Doutorado em Educação)—Pontifícia Universidade Católica de São Paulo: São Paulo.

Morin, E. (1992). O método IV. As idéias: A sua natureza, vida, habitat e organização. Portugal: Publicações Europa-América.

Piaget, J. (1973). Seis Estudos de Psicologia. (M. A. M. D’Amorim.: Trad.). Rio de Janeiro: Editora Forense Universitária LTDA. (Original publicado em 1964).

Prigogine, I., \& Stengers, I. (1979). La Nouvelle Alliance: Metamorphose de La Science. Paris: Gallimard.

Piaget, J., \& Garcia, R. (1987). Psicogênese e história das ciências. Lisboa: Dom Quixote.

Rechikian, A. (1993). Os Filósofos e a Educação. Lisboa: Colibri.

Santos, B. S. (1997). Um discurso sobre as ciências (9th ed.). Porto: Edições Afrontamento.

Santos, B. S. (2005). A Crítica da Razão Indolente: Contra o desperdício da experiência (5th ed.). São Paulo: Cortez.

Vygotsky, L. S. (1999). A Formação Social da Mente. São Paulo: Martins Fontes. 